\title{
Sorghum technology adoption using the innovation platform
}

\begin{abstract}
Since the establishment of the Zambia Agriculture Research Institute (ZARI) in 1953 formerly called Soils and Crops Research Branch (SCRB), the Sorghum and Millets Improvement Programme (SMIP) at ZARI has been utilizing conventional breeding methodologies to disseminate agricultural technologies. The introduction of the Cytoplasmic Male Sterility (CMS) in the early 80 s as a way to accelerate seed production of new plant varieties was full of optimism. When the CMS system was first introduced, hopes were very high for rapid progress in hybrid seed production and so were the hopes for high technology adoption rates of new varieties. However, despite the breeding efforts, the adoption rates of new plant varieties have been modest especially for hybrids. Some of the failures have been attributed to the top down approach, where the development of a variety starts with a breeder and then ends up in the hands of a farmer. In certain instances this methodology has worked perfectly as is the case for maize, if supported by the policy frame works. In order to encourage utilisation of proven technologies from agricultural research, innovative methods have had to be adopted since 2007 using a concept called Participatory PreBreeding and Variety Selection. This is a borrowed concept from social scientists on participatory rural appraisal to bring about rural agriculture development. The idea behind this was to improve agriculture production and productivity by increasing the adoption rates of technologies for underutilised crops that are otherwise important for climate change adaptation and food security. This was done by evolving major stakeholders in the developmental and dissemination process. The selection process of promising varieties started in farmers' fields, if at all they saw the need for the technology. Sometimes the technology adoption process was driven by the demand for a particular variety of sorghum by companies requiring malting. This way, farmers had an incentive to adopt a variety easily because there was a market for it. This process was then facilitated by all stakeholders to make sure that is the technologies desired on the market or by the farmers were delivered. This approach lead to the release of a red sorghum variety (ZSV-36R) that was otherwise underutilised before this approach was implemented.
\end{abstract}

Keywords: ZSV-36R; Sorghum
Volume 2 Issue 2 - 2015

\author{
Lloyd Mbulwe \\ Zambia Agriculture Research Institute, Zambia
}

Correspondence: Lloyd Mbulwe, Zambia Agriculture Research Institute, Private Bag 7, Chilanga, Zambia,Tel: +260964l47968, Email maclloydm@yahoo.com

Received: October 27, 2014 | Published: April 13, 2015
Abbreviations: ZARI, zambia agriculture research institute; SMIP, sorghum and millets improvement programme; SCRB, soils and crops research branch; CMS, cytoplasmic male sterility; FAO, food agriculture organisation; BI, biodiversity international; UNEP, united nations environmental programme; EBAs, ecosystems based approaches; BCN, biodiversity community network; NPGRC, national plant genetic resources, JICA, Japanese international cooperation, FARA, forum for agriculture research in Africa; IPTA, innovation platform for technology adoption; DUS, distinct uniform and stable; $\mathrm{CBD}$, convention on biological diversity; IT-PGRFA, international treaty for plant genetic resources for food and agriculture; TRAIPS, trade related aspects of intellectual property rights; VR, variety registration; PBR, plant breeders rights; PVP, plant variety protection; FR, farmers rights; TK, traditional knowledge; IPR, intellectual property rights; GIs, geographical indicators

\section{Introduction}

Even though high yielding improved sorghum varieties and hybrids have been released in Zambia, the adoption rates of these technologies have been modest. ${ }^{1}$ The seed of these improved technologies is not readily available from the various seed producers. ${ }^{2}$ The low adoption rates for improved technologies have been attributed to a number of factors. Seed companies that were tasked to be conduits of government released varieties have failed to deliver citing low demand and the high cost of distributing the seed in far flung areas. This has been cited as one of the many contributing factors to the low adoption of these varieties.

On the other hand the underutilisation of sorghum has been associated with the poor social perception people have of sorghum. For a long time now sorghum has been considered a staple crop for Africa's most food insecure people. This already has some negative effect on the image of sorghum as a food crop. ${ }^{3}$ On the contrary, sorghum grain are valued for stocked-feed and human nutrition, ${ }^{4}$ while the stalks are valued for silage and many other value added products such as sugar production in India. ${ }^{5}$ In the United States of America alone 6.8 million hectares of sorghum have been reported under sorghum production before and China consumes a whopping30million tons of grain annually since $2009 .^{6}$ 
There are many publications citing that sorghum is a crop most suitable for people who live in the desert margins, semiarid tropics and drought affected areas, ${ }^{3,7}$ as a result there is a tendency to promote sorghum mostly in drought affected areas. While this is true, it is also a fact that sorghum can be grown in a wide range of environments. Sorghum is widely adapted and is tolerant to drought and water logging, ${ }^{7}$ and grows in various soil conditions. ${ }^{8}$

In Zambia, there seems to be some kind of belief that sorghum is a food crop for the poor and it is treated as such. ${ }^{9}$ This probably explains why middle class households rarely consume sorghum and therefore depriving themselves of the health benefits of sorghum. ${ }^{10}$ On the other hand the majority of Zambians have a preference for maize despite the fact that sorghum is highly similar to maize. ${ }^{11,12}$ In fact sorghum and millets were among the preferred staple crops in Zambia before maize was introduced probably by the early European explorers in the $16^{\text {th }}$ century. ${ }^{13}$ Since sorghum can also be processed using technologies of dry and wet milling applied to maize ${ }^{3}$ sorghum and maize should be more or less treated the same in terms of consumption.

When it comes to growing white sorghum the biggest complaint by the farmers is that birds cause huge yield losses because they have a preference for white sorghum ${ }^{14}$ and many use this as an excuse not to grow sorghum. Nonetheless, sorghum is not the only crop affected by birds but also sunflower, wheat, rice and in certain instances maize. Growing larger hectares alleviates this problem in all these crops. An Improved red sorghum variety called ZSV-36R was developed by $\mathrm{SMIP}^{15}$ to help alleviate this problem in areas where birds are a problem especially in game parks. Farmers growing white varieties can switch to growing red especially if they are growing it for sale, because some companies do purchase red sorghum for malting this has helped to alleviate the problem of market as well.

The other widely held misconception is that all sorghum contains tannins and that tannins are food anti-quality factors. Although tannins are considered food anti-quality factors by food nutritionists ${ }^{16}$ not all sorghum contain tannins. ${ }^{17}$ Tannins can also be denatured by heating to $210^{\circ} \mathrm{C}$. New research on tannins reveals that Phenolic acids, flavonoids, 3-deoxyanthocyanins and condensed tannins found in sorghum have potential health benefits-antioxidants.

The poor publicity of sorghum in the past is perhaps the principal contributing factor to the low adoption rates and it's under utilization. However, International Organisations such as the Food Agriculture Organisation (FAO), Biodiversity International (BI) and United Nations environmental Programme (UNEP) have been concerned about the loss of biodiversity resulting from the underutilisation of crops such as sorghum for food security, climate change adaptation and economic empowerment. ${ }^{18}$ Other reasons for the biodiversity loss may have resulted from variety replacement, land clearing, overexploitation of species, population pressure, environmental degradation, overgrazing, and difficulties in implementing governmental environmental policies, changing agricultural systems and indeed global climate change..$^{19,20}$

But, the loss of agricultural biodiversity has been largely due to variety replacement of local germplasm imposed by modern day agriculture. ${ }^{21}$ Commercial varieties of maize introduced into traditional farming systems have also resulted in the displacement of local varieties of sorghum even in areas where maize is not suitable. ${ }^{13}$ Another problem related to agro-ecosystem biodiversity loss is the development of distinct, uniformity and stable varieties to conform to modern day agriculture grown over large areas. ${ }^{22}$

The importance of sorghum in this era of global climate change cannot be over emphasised and perhaps people are not well informed on the real value of sorghum. To address this problem several approaches have been proposed such as advocating for the crop diversification in national agricultural systems, ${ }^{2}$ utilisation of Ecosystems Based Approaches (EBAs) for climate change adaptation, ${ }^{23}$ and Participatory Pre-breeding and Variety Selection which is a fairly recent approach. ${ }^{24}$ Other ideas for utilization and conservation of sorghum biodiversity include conservation (in situ), gene banks or seed banks (ex situ) and human assisted breeding (pre-breeding and conventional). This offers a good balance between biodiversity conservation and meeting the demands of food security using modern agriculture.

\section{Methodology}

In 2007, a base line survey was conducted to determine the status of sorghum technology adoption and other underutilised crops in Zambia. ${ }^{2}$ The major finding was the unavailability of seed and marketing challenges. Farmers don't just grow crops for food security but also to generate income for other basic necessities such as health, education and social-economic wellbeing. Other findings included insufficient information on value addition and markets. ${ }^{9}$ On the other hand processing companies are willing to utilise sorghum but are unable to find a reliable supply of sorghum from the farmers locally and so some companies resorted to importing sorghum from other countries for malt. Other stakeholders did not even know that sorghum is an important crop in the food, feed and fuel industry.

Upon realising these challenges stakeholder consultative meetings where arranged to identify partners in sorghum technology dissemination and utilization. Participatory methodologies where widely utilised in making sure that farmers are involved in the technology adoption process by making sure that they themselves saw the need to adopt the technologies for their own social-economic empowerment. This was then followed by searching for the genetic materials to test with the farmers and finally experimentation onfarm in order to disseminate appropriate varieties. On farm meetings, demonstration plots, farmer field schools, field days, experimental trials, agriculture shows, trainings and seed production where some of the tools that were particularly useful to identify which traits were preferred by the farmers. Even within the farming community there was a huge diversity among the farming community on the preferred materials because each farmer's preference was different. Suitable varieties were then selected together with the farmers and collected from gene banks, breeders and farmers. This also included newly released varieties or promising ones. The materials were then evaluated collectively using experimental designs that where more user friendly for the farmers such as demonstration plots and participatory methods like farm walks and field schools. Information was collected on a number of things such as the number of farmers growing sorghum, the areas where sorghum is grown, seed availability, market availability for sorghum, yield performance of sorghum under farm conditions, and other constraints associated with sorghum production and productivity. Not all the data that was collected is shown in this paper.

The Pre-Breeding approached has been tried in the dry land areas of Zambia along the Luangwa and Zambezi river basins in the agroecological region one (i) of Zambia. The selection of varieties of 
sorghum with desirable characteristic started with the farmer or the end user in this case a company involved in sorghum utilisation to get desirable characteristics. These characteristics ranged from tolerance to both biotic stress such as diseases and pests and abiotic stress such as tolerance to drought, heat and specific soil conditions (acidity, low soil fertility and water logging) to quality traits such as nutritional benefits, flavour and grain colour. Figure 1 Participatory pre-breeding and variety selection ensured the sense of ownership by the farming community.

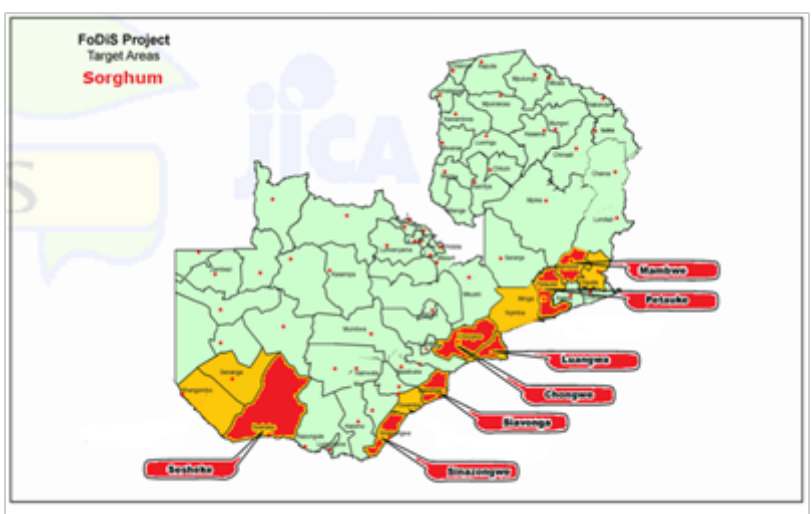

Figure I Areas where participatory pre-breeding and variety selection has been has been utilised.
Whereas before the farmers did not feel the need to grow a particular variety for food security, climate change adaptation or for the market. This has been an effective way of deploying plant genetic materials that are underutilised at an on farm experiment in order to meet the expectations of a farmer and the processing industry. This allowed the breeders to understand better what qualities are preferred by the producers (farmers) and consumers (industry). The production of a suitable variety to meet the needs of both was a collaborative effort. $^{25}$

In collaboration with Biodiversity Community Network (BCN), The National Plant Genetic Resources (NPGRC), Japanese International Cooperation (JICA), Forum for Agriculture Research In Africa (FARA), famers, processing industries and Stakeholders Participatory Pre-Breeding was used in seven (7) districts of Zambia namely Mambwe, Petauke, Luangwa, Chongwe, Siavonga, Sinazongwe and Sesheke Districts. The Innovation Platform for Technology Adoption (IPTA) is all about coming together and resolving problems collectively(Figure 2).

In the innovative matrix (plant form) everybody is involved and is part of the developmental process. While in the conventional approach technology dissemination moves from the breeders and handed down in a linear channel through extension to the farmer and thereby creating a bottle neck for information flow and technology adoption at the bottom end.
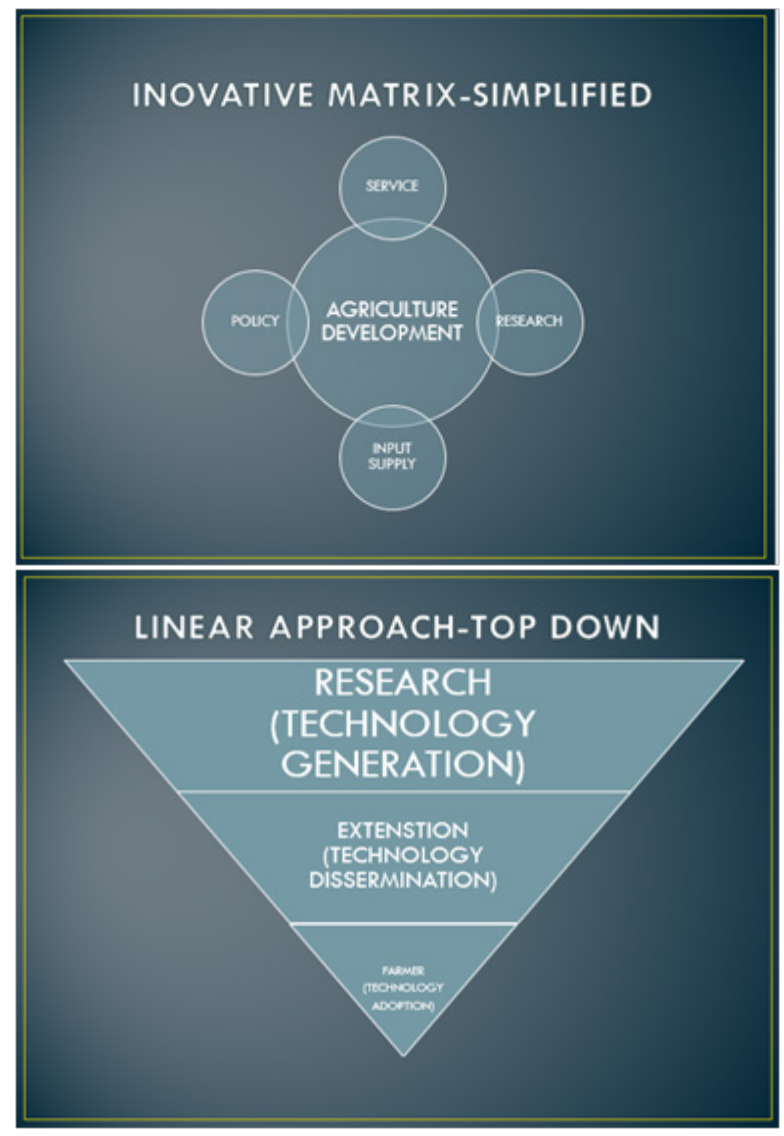

Figure $\mathbf{2}$ The difference between the innovative platform for participatory plant breeding and conventional approaches. 


\section{Results}

Tables 1-6

Table I Yield Performance of ZSV-36 Rusing pre-breeding and variety selection

\begin{tabular}{ll}
\hline Variety & Average Yield (Kgs/ha) \\
\hline ZSV-36R & 2958 \\
Sima & 3154 \\
Kuyuma & 3007 \\
\hline
\end{tabular}

Table 2 Characteristics of varieties used in participatory pre-breeding and variety selection

\begin{tabular}{llll}
\hline Variety & Days to $\mathbf{5 0} \%$ flower & Plant height $\mathbf{( c m )}$ & Grain color \\
\hline ZSV-36R & 74 & 180 & RED \\
Sima & 78 & 259 & WHITE \\
Kuyuma & 72 & 235 & WHITE \\
\hline
\end{tabular}

Table 3 Seed production by farmers for the cottage industry using participatory pre-breeding and variety selection

\begin{tabular}{ll}
\hline $2008 / 2009$ & $2,300 \mathrm{kgs}$ \\
$2009 / 2010$ & $2,500 \mathrm{kgs}$ \\
$2010 / 2011$ & $4,500 \mathrm{kgs}$ \\
Overall Totals & $9,300 \mathrm{kgs}$
\end{tabular}

Table 4 Seed production for the cottage industry using participatory pre-breeding and variety selection

\begin{tabular}{lll}
\hline Year & Farmer (ha) & Kgs \\
\hline $2008 / 2009$ & $488(122 \mathrm{ha})$ & 2440 \\
$2009 / 2010$ & $670(167.5 \mathrm{ha})$ & 1340 \\
$2010 / 2011$ & $1,556(389 \mathrm{ha})$ & 3112 \\
$2011 / 2012$ & $1,500(375)$ & 3000 \\
Overall totals & $4214(1053.5)$ & 9892 \\
\hline
\end{tabular}

Table 5 Industrial Sorghum consumption in Zambia in the year 2012 following market linkage efforts

\begin{tabular}{ll} 
Company & Consumption tones/annum \\
\hline Zambia Breweries Private Limited Company: Eagle Lager Production & 2,500 \\
Kankoyo Breweries: Opaque beer production & 300 \\
Tiger Animal Feeds: Stock-feed for urban small (pigeons and quells) & 12 \\
Transcontinental: Stock-feed for fish production & 96 \\
Other breweries: Opaque beer production & 150,000 \\
Zambeef silage for dairy animals (milk production) & 12,000 \\
Kapiri Breweries & 18 \\
Total & $\mathbf{1 6 4 , 9 2 6}$ \\
\hline
\end{tabular}


Table 6 Beneficiaries of participatory technology dissemination

\begin{tabular}{|c|c|}
\hline Direct beneficiaries-small scale farmers project areas & $\begin{array}{l}1055 \text { beneficiaries [525 men and } 530 \\
\text { women] }\end{array}$ \\
\hline 1.Men & 525 \\
\hline 2. Women & 530 \\
\hline Indirect Beneficiaries-Small scale farmers project areas & 525 Beneficiaries [ 260 men and 265 women] \\
\hline 1.Men & 260 \\
\hline 2. Women & 265 \\
\hline Indirect Beneficiaries-Small Scale Farmers Non-Project Areas & 300 Beneficiaries \\
\hline 1.Rufunsa & 100 \\
\hline 2.Chongwe & 200 \\
\hline Indirect Beneficiaries-Large Scale Farmers Non-Project Areas & 4 Beneficiaries \\
\hline 1.Medson [Chibombo] & 1 \\
\hline 2.Kamona [Chibombo] & 1 \\
\hline 3.Mulwani [Kalomo] & 1 \\
\hline 4.Bignell [Mazabuka] & 1 \\
\hline
\end{tabular}

Value Chain and Market Linkages-Direct Beneficiaries Sorghum Processing Companies 5 Beneficiaries

1.Zambia Breweries 1

2.Nkosi Breweries 1

3.Mukwa Breweries 1

4.Kankoyo Breweries 1

Kapiri Breweries 1

Value Chain Approach-Indirect Beneficiaries Sorghum Processing Companies 3 Beneficiaries

1.Nkwazi Beer 1

2.Lusaka Beer 1

3.Chat Breweries 1

Networking and collaboration-Indirect Beneficiaries Sorghum Marketing Companies/ Businesses

1.Joyce

8 Beneficiaries

2.Ruth

3.Martha

4.Dorcus

5.Simukonda

6.Grain Traders Association of Zambia [GTAZ]

1

1

1

1

1

7.Commodity Holding Company [CHC]

8.Zambia Agriculture Commodity Exchange [ZAMACE]

1

\section{Training Workshops Direct Beneficiaries}

1.First Stakeholders Workshop IPTA

2.Second Stakeholders Workshop IPTA

1

144 Beneficiaries [Representing 54 Stake Holders]

10 [Representing 7 stake holders]

26 [Representing 14 stake holders]

28 [Representing 16 stake holders]

3.Third Stakeholders Workshop IPTA

32 [Representing 5 stake holders]

4.Market Linkage Workshop Masaiti

24 [Representing 7 stake holders]

5.Market Linkage Workshop Siavonga

24 [Representing 5 stake holders] 


\section{Discussion}

Technology development and innovation helps to improve the adaptability of crops that may not be suitable to certain agroecological regions. The idea behind the participatory approach is to provide an opportunity for a farmer to choose a wide range of available germplasm to enhance biodiversity (genetic variability). Through the natural selection process, pre-breeding, conventional breeding and biotechnology, plant varieties have been developed that have a better ability to adapt to the changing weather conditions. Involvement of farmers helps to disseminate the improved materials in a much faster way and adoption is almost always guaranteed.

When more farmers were able to access the germplasm, the end result was a sense of ownership and this helped farmers serve their own seed at community level, especially for plant genetic materials that were neglected by seed companies such as sorghum. This forms the basis of ecosystems based approaches for sustaining biodiversity of such crops because the selection process is based on adaptability to the natural environment.

In traditional selection methods (Pre-breeding) a relatively small gene pool is created and there is not a lot of opportunity for gene recombination and few opportunities exist for new plant varieties to be created. Many selections done by traditional methods resulted from spontaneous mutations that occur naturally over time and some of these mutations may not offer any adaptive advantages and may be deleterious in nature. Despite this, there are still many traditional plant varieties and wild type plants that can be exploited for food security and are good candidates for ecosystems based approaches for the sustainability of biodiversity. One good example is rape-seed (Brassica Napus L) ${ }^{26}$ and other grains like amaranths and Rottboellia exaltata are a few examples. Even though Rottboellia is mainly considered as a noxious weed ${ }^{27,28}$ it could be exploited as a future grain crop.

Populations derived from natural self-pollination or even cross pollination are sometimes not as evolutionary adaptable but are known to utilize specific ecological niches more effectively. As a result conventional breeding is utilised to improve the adaptability of such crop species to their own natural environments. However in conventional breeding it is usually traits with high heritability that are quick and easy to measure that are selected and many argue that this method drastically decreased other traits in later generations. However modern agriculture requires that a variety is Distinct Uniform and Stable (DUS) and this forms the basis of variety registration and release before seed can be produced. For commercial production to be viable seed needs to be pure for certain industrial processes such as chemical extraction. Without modern day breeding certain industrial processes would be a lot more challenging. Unfortunately, modern agriculture has been blamed for displacing of traditional varieties.

Policies need to be made or revised (amended) to ensure that agriculture is sustained in this era of global climate change. Conversely, it is important that when policies are made they should benefit the farmers. The most important policies include agriculture and environmental policies and they should be made in such a way that even farmers are able to benefit from them. Because Zambia is a signatory to a number of International conventions the international policy frame work also needs to be taken into consideration such as the Convention on Biological Diversity (CBD), International Treaty for Plant Genetic Resources for Food and Agriculture (IT-PGRFA) and The Agreement on Trade Related Aspects of Intellectual Property Rights (TRIPS). These international frameworks if used effectively could help farmers have more benefits from their biodiversity. ${ }^{29}$

\section{Conclusion}

Since participatory pre-breeding has been fairly successful it will be extended to cowpeas. There is value for cowpeas to contribute to soil improvement, food security, climate change adaptation, and social economic-empowerment..$^{30}$ In order to strengthen participatory plant breeding additional efforts will include use of innovative technologies since it is evident that farmers do not only need food security but money to allow them access clean water, shelter, education and health. ${ }^{31}$ Therefore innovative ways of utilizing crops that are considered underutilised is a must, one of the ways this can be achieved is to promote value addition and innovative ways to utilise them.

Scientific research has revealed that most of these underutilised crop species have a lot of nutritional value. For example, sorghum is beneficial to individuals with diabetes. ${ }^{10}$ Promoting sorghum as a food crop with health benefits and other uses can easily find use in urban markets in a processed form and farmers could earn incomes from crop sales. ${ }^{9}$ Utilising various varieties for different end users will also promote crop diversification and an increase in biodiversity.

Secondly the existing policy frame works can be harnessed such as, Variety Registration (VR), Plant Breeders Rights (PBR), Plant Variety Protection (PVP), Farmers Rights (FR), Traditional Knowledge (TK), Intellectual Property Rights (IPR) and Geographical Indicators (GIs) to explore further how well these policies can help farmers.

The financial institutions in Zambia need to find better funding mechanisms to micro-finance farmers because this is a key to national development so that farmers can invest in increased productivity and production. It is also important to realise that from a scientific perspective most farmers in the current era have a low genetic base because of germplasm loss and in most cases they are growing crops that are not suitable in particular ecosystems. Farmers in region one (i) need to grow crops that are more adaptable to the environment they live in because this will help improve food security.

In a country that is still developing it is important to realise that training and information sharing should still be emphasised because training and information sharing will help both the farmer-breeder and the conventional-breeder have better knowledge on how they can access germplasm for breeding and other uses.

Big private seed companies have shunned away from investing in seed production for underutilised crop species therefore there is still need to help develop-the cottage seed industries by promoting small seed companies to produce seed in remote rural areas. Most seed companies are not willing to invest in seed for underutilised crop species in remote rural areas sighting high investment costs and low returns on their investments yet even remote rural farmers also require high quality planting materials. This can be partially resolved by assisting farmers re-establish or develop their own local seed industry.

At the end of the day in order to preserve the crop biodiversity, encouraging the sense of ownership of the genetic materials by farmers using some of the international agreements on the utilisation of plant genetic resources like farmers' rights, traditional knowledge and benefit sharing will encourage farmers to have a sense of ownership over the genetic material that they possess in their communities and 
hence promote their utilisation for food security, climate change adaptation, soil improvement and social-economic wellbeing and hence preserving biodiversity.

\section{Acknowledgements}

None.

\section{Conflict of interest}

The author declares no conflict of interest.

\section{References}

1. Chisi M, Anandajayasekeram P, Martella D, et al. Impact assessment of sorghum research in Zambia. Southern African Center for Cooperation in Agricultural and Natural Resources Research and Training (SACCAR); P/B 00108, Gaborone, Botswana; 1997.

2. Mukelabai N, Moses SCS, Martin C, et al. Food Crop Diversification Support Project for Enhancement of Food Security in Zambia (FoDiS). Zambia: Japan International Cooperation Agency (JICA) Zambia office Lusaka; 2007.

3. Taylor JR, Dewar J. Developments in sorghum food technologies. $A d v$ Food Nutr Res. 2001;43:217-264.

4. Dahlberg JA, Wasylikowa K. Image and statistical analyses of early sorghum remains (8000B.P.) from the Nabta Playa archaeological site in the Western Desert, Southern Egypt. Vegetation History and Archaeobotany. 1996;5(4):293-299.

5. Anil KY, Nirichan KB, Ambalal BC, et al. Production of L (+) lactic acid from sweet sorghum, date palm, and golden syrup as alternative carbon sources. Starch. 2011;63(10):632-636.

6. Tsao GT, Pingkai O, Jian C. Biotechnology in China II: chemicals, energy and environment. Advances in Biochemical Engineering/Biotechnology. 2010;122:77-78.

7. Doggett H. Sorghum. 2nd ed. London, New York, Longman: published by Wiley; 1988.

8. Dillon SL, Lawrence PK, Henry RJ, et al. Sorghum resolved as a distinct genus based on combined ITS1, $n d h F$ and Adhlanalyses. Plant Systematics and Evolution. 2007;268(1-4):29-43.

9. Forum for Agricultural Research in Africa (FARA). Making things happen: stories from the field. FARA Publications. 2012;1:43-48.

10. Ciacci C, Maiuri L, Caporaso N, et al. Celiac disease: invitro and invivo safety and palatability of wheat free sorghum food products. Clin Nutr. 2007;26(6):799-805.

11. James M. Maize and Grace: History, Corn, and Africa's New Landscapes, 1500-19991. Boston University. 2001;43(2):246-272.

12. Haug A, Christophersen OA, Kinabo J, et al. Use of dried Kapenta (Limnothrissa miodon and Stolothrissa tanganicae) and other products based on whole fish for complementing maize-based diets. African J Food, Agric, Nutrition Development. 2010;10(5):2478-2499.
13. Japan association for international collaboration of agriculture and forestry (JAICAF). The Maize in Zambia and Malawi. 2008.

14. Russell GE. Progress in plant breeding. Eslevier. 2013;1:207-208.

15. SCCI.) Seed control and certification institute. Official Variety Register 2014. Produced by the VRC secretariat, Seed Control and Certification Institute; 2014

16. Praveen KA, Kumund U. Tannins are Astringent. $J$ Pharmacology and Phytochemistry. 2012;1(3):1-6

17. Awika JM, Rooney LW. Sorghum phytochemicals and their potential impact on human health. Phytochemistry. 2004;65(9):1199-1221.

18. Boelee E (Ed). Ecosystems for water and food security. Nairobi: United Nations Environment, Programme (UNEP); Colombo: International Water Management Institute (IWMI); 2011. 194 p

19. Richard F. Genetics and extinction. Biological Conservation 2005;126(2):131-140.

20. Sullivan SN. Plant genetic resources and the law: past, present and future Plant Physiol. 2004;135(1):10-15.

21. O’Brien SJ. Genetic Erosion. A global dilemma. Natl Geogr. 1992;181:122136.

22. UPOV. International Union for the Protection of New Varieties of Plants Geneva. Guidelines for the conduct of tests for distinctness, homogeneity and stability (Sorghum bicolor L.); 1989.

23. United Nations Environment Programme (UNEP). Africa Adaptation Gap Technical Report: Climate-change impacts, adaptation challenges and costs for Africa; 2013.43 p.

24. Salvatore C. Efficiency of plant breeding. Crop Sci. 2015;55:87-97.

25. Food and Agriculture Organization of The United Nations. Report of the First Session of the Governing Body of the International Treaty on Plant Genetic Resources for Food and Agriculture. Madrid, Rome, Italy; 2006.

26. Liu YB, Wei W, Ma, et al. Backcrosses to Brassica napus of hybrids between B. juncea and B. napus as a source of herbicide-resistant volunteer-like feral populations. Plant Sci. 2010;179(5):459-465.

27. House LR, Mughogho LK, Peacock JM. Sorghum in the Eighties: Proceedings of the International Symposium on Sorghum. ICRISAT (International Crops Research Institute for the Semi-Arid Tropics), Patancheru, AP, India; 1982;1:2-7.

28. Cyrus N, Gebisa E, Greg E, et al. Report of the Sixth External Program and Management Review (EPMR) of the International Institute of Tropical Agriculture (IITA). Science council CGIAR; 2007. A90 p.

29. The United Nations Framework Convention on Climate Change; 1994.

30. Mullen C. Summer legume forage crops: cowpeas, lablab, soybeans. NSW Department of Primary Industries. Broadacre crops, Agfact; 1999. 16 p.

31. Pannella DJ, Llewelly RS, Corbeels M. The farm-level economics of conservation agriculture for resource-poor farmers. Agriculture Ecosystems and Environment. 2013;187:52-64. 